\title{
COMPARATIVE ANALYSIS OF NEUROINTERFACE TECHNOLOGIES FOR THE PROBLEM OF THEIR REASONABLE CHOICE IN HUMAN-MACHINE INFORMATION SYSTEMS
}

\author{
Roman Butsiy ${ }^{1}$; Serhii Lupenko²
}

\author{
${ }^{1}$ Institute of Telecommunications and Global Information Space, Kyiv, Ukraine \\ ${ }^{2}$ Ternopil Ivan Puluj National Technical University, Ternopil, Ukraine
}

\begin{abstract}
Summary. The market of modern neurointerfaces, despite its active development, unfortunately, can offer users only a number of existing prototypes that have a relatively low accuracy and identification reliability of the human operator control effects. In addition, any neurointerface on the market must be individually tailored to each operator, which makes it difficult to objectify its accuracy, precision and reliability. The first step in solving the above problems is to conduct a comparative analysis of different price segments of the market of existing neurointerface technologies, as presented in this article. The market research revealed that despite the disadvantages of electroencephalography, it is one of the most accessible non-invasive methods of recording biological signals in neurointerface systems. To facilitate future research, the main advantages and disadvantages of known models and methods of signal analysis in neurointerfaces have been considered and analyzed. In particular, in the context of signal pre-processing, advantages and disadvantages of such methods as Common Average Referencing, Independent Component Analysis, Common Spatial Patterns, Surface Laplacian, Common Spatio-Spatial Patterns and Adaptive Filtering are considered. At the stage of evaluating the informative characteristics of the signal, the analysis of models and methods based on the models of adaptive parameters of autoregression, bilinear autoregression, multidimensional autoregression, fast Fourier transform, wavelet transformation, wave packet decomposition is performed. Besides, a comparative analysis of the most common methods of identification (recognition) of control effects of the human neurointerface operator, namely, the method of discriminant analysis, the method of reference vectors, nonlinear Bayesian classifiers, classifiers of nearest neighbors, artificial neural networks is carried out. The study of neurointerface technologies provides researchers with additional grounds for a sound choice of mathematical, software and hardware of neurointerface systems, as well as contributes to the development of new versions with increased accuracy, reliability and reliability.
\end{abstract}

Key words: neurointerface, cassification, signal processing, comparative analysis, EEG.

Statement of the problem. Despite the rapid and global development of modern information technology, human interaction with computer systems is still based on not very convenient means of communication, namely, the use of inertial technical interfaces such as keyboard, mouse, graphics tablet, which is a bottleneck in communication between the human operator (user) and the computer system operated [1]. In other words, modern technologies of human-computer interaction are asymmetric [2], which is caused by the lack of reliable technological solutions in the field of neurointerface technologies.

A neurointerface is a device that allows wired or wireless information exchange between the brain and any external electronic device. The desired result in the control of such a device can be achieved by controlling it with a reverse controller, the input of which is a simple command signal generated by a human operator. This approach allows the neurointerface to identify (recognize, detect) the choice of command made by a person and, consequently, to ensure the execution of this command by means of a controlled system. Thus, even an unqualified operator can easily control any external device/system using a neurointerface. The main tasks of the neurointerface are measurement of brain activity signals, identification 
(recognition, detection) of control effects and their transformation into control signals of a certain external device/system.

Analysis of available investigation results. Nowadays, the worlds leading research institutions and companies are actively working on the development of neurointerface technologies and their application to human-computer interaction, in particular, in the field of biomedical engineering, neuroprosthetics, etc. They form an additional communication channel that can be used as an explicit output (for example, conscious transmission of a command), or an implicit output (for example, obtaining information about the user's status, which is automatically read from his current brain activity).

In July 2016, the startup «Neuralink» was founded, the team of which included: Paul Merolla, Vanessa Tolozu, Dongjin Seo, Tim Gardner. In the summer of 2020, the company introduced a prototype of the neurointerface «Link» v0.9, which is designed to solve the above problems, but today this technology still needs significant refinement [3]. There are many modern studues on neurointerface technologies. Development and research in this area is carried out continuously, is proved by the large number of peer-reviewed articles over the past twenty years (Fig. 1). The data were obtained with Science Direct search engine.

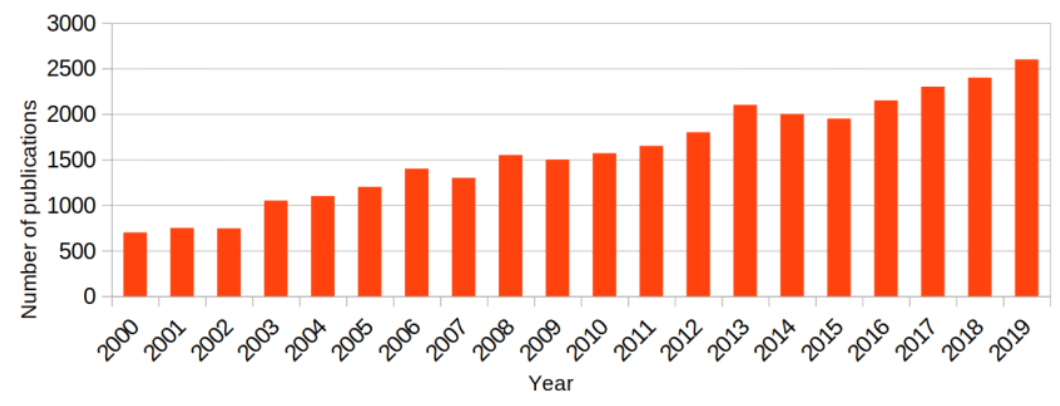

Figure 1. Number of publications on neurointerfaces over the past 20 years

Jerry J. Shih, MD, in his article [4] Brain-Computer Interfaces in Medicine, says that neurointerfaces can control many different devices, from cursors on computer screens to wheelchairs and robotic prostheses. But the author emphasizes that neurointerfaces still need their reliability and accuracy of methods in recognizing operator commands to be improved.

The objectives of the research is to conduct a comparative analysis of existing neurointerfaces and methods of processing biometric data in them, to identify their advantages and disadvantages for the problem of informative choice of neurointerface for research and direction of improvement of neurointerface technologies.

Statement of the task. Given the large number of scientific researches and the availability of neurointerface systems from different manufacturers, it is necessary to conduct a systematic comparative analysis of known neurointerfaces, methods for measuring information signals of human brain activity, methods of identification (recognition) of control effects and an other technical and economic characteristics.

Neurointerface performance can be described by two main characteristics:

- operation speed, which is determined by the time spent on the user's choice recognition;

- accuracy, which is determined by the frequency of correct recognition of the user's choice.

Existing neural interface systems make it possible to recognize a user's choice in a matter of seconds with relatively high accuracy. For example, in the recognition of two states (yes or no), moving the arrow on the screen monitor, the accuracy reaches $90 \%$. However, the information recognition rate is quite low (i.e. from 5 to $25 \mathrm{bits} / \mathrm{min}$ ) [5]. This is due to the fact that speed and accuracy are closely linked, and, for example, the higher is speed, the lower accuracy is and vice versa - with increase of accuracy, the recognition speed will decrease. 
Signals of brain activity (i.e. electrobiological potentials) in neurointerfaces are recorded in both invasive and non-invasive ways. If brain activity is recorded from the surface of the scalp, such a neurointerface is called non-invasive. Then, if brain activity is recorded from the surface of the cerebral cortex, or from individual neurons, such a neurointerface is invasive. In some sources, there are also semi-invasive neurointerfaces. In this classification, if brain activity is recorded from individual neurons, such neurointerface is invasive, and if brain activity is registered only from the surface of the cerebral cortex, such neurointerface is called semi-invasive. In this article we follow the first classification of neurointerfaces (Table 1).

Table 1

Classification of neurointerfaces according to the method of connection to the user

\begin{tabular}{|c|c|c|}
\hline \multirow{2}{*}{ Features } & \multicolumn{2}{|c|}{ Types of neurointerfaces } \\
\cline { 2 - 3 } Accuracy & $\begin{array}{c}\text { Low because the electrodes do not directly } \\
\text { contact with the brain, but register the } \\
\text { electromagnetic field on the surface of the } \\
\text { head }\end{array}$ & $\begin{array}{c}\text { High because the electrodes are on the } \\
\text { surface of the cerebral cortex or connect } \\
\text { directly to neurons }\end{array}$ \\
\hline $\begin{array}{c}\text { Way of connection with } \\
\text { brain }\end{array}$ & $\begin{array}{c}\text { Electrodes are on the surface of the scalp; } \\
\text { for some types of electrodes a special } \\
\text { conductive gel is used }\end{array}$ & $\begin{array}{c}\text { Electrodes are implanted directly into the } \\
\text { cerebral cortex or are on its surface }\end{array}$ \\
\hline occur during use & $\begin{array}{c}\text { Due to low accuracy, it is necessary to use } \\
\text { additional methods for signal analysis and } \\
\text { processing; before every use, the } \\
\text { neurointerface needs to be pre-configured }\end{array}$ & $\begin{array}{c}\text { Corrosion of electrodes; fouling of } \\
\text { electrodes by connective tissue, which } \\
\text { leads to worsening of contact; contact of } \\
\text { brain cells with electrodes may cause their } \\
\text { death }\end{array}$ \\
\hline
\end{tabular}

Although the accuracy and speed of invasive neurointerface recognition is higher than non-invasive, their use is significantly limited. This is due to the fact that its installation requires the services of a qualified neurosurgeon to perform complex surgery, which in turn can lead to complications in the patient's health. It should be noted that most experimental invasive neurointerfaces do not involve long-term use due to corrosion of electrodes, their fouling with connective tissue, which leads to deterioration of contact or its loss and complicates the process of their removal from the brain, and so on. Hence there is a need to install an invasive neurointerface only for the duration of the experiment. Considering the above factors, noninvasive neurointerfaces have become the most popular.

The market of neurointerfaces is represented by only a few companies, but due to the increase of use and demand for them, over the past 5 years there has been a sharp increase in supply of this product. Each manufacturer offers something unique to the consumer - whether the number of channels, stationary or portable device, pre-defined indicators or, of course, the price [6] (Table 2).

According to the table it can be seen that the market of neurointerfaces is divided between several players who produce devices with different characteristics. Commercially available neurointerfaces can be divided into three price ranges: lower range, middle range and upper range. At the beginning of the lower price range $(\$ 100-\$ 1,000)$ there are devices with the fewest sensors, in particular, companies such as NeuroSky and Muse offer neurointerfaces that help improve meditation and sleep, although their research potential of such devices is significantly limited. Emotiv offers 5- and 14-channel neurointerfaces, which have much greater potential for identifying control signals by processing primary signals of brain activity. Emotiv also has solutions for 32 channels in the highest price range. All of the above devices have a wireless connection, which allows the patient to move more freely. You can order an 
Comparative analysis of neurointerface technologies for the problem of their reasonable choice in human-machine information systems

OpenBCI device and print the headset for it yourself on a 3D printer. The organization strives for open access and cost-effective solutions for neurointerfaces, providing enhanced opportunities for approach to brain research.

Table 2

Characteristics of available neurointerfaces offered by the market

\begin{tabular}{|c|c|c|c|c|c|c|c|c|c|c|c|}
\hline \multirow[b]{2}{*}{ Indicator } & \multicolumn{11}{|c|}{ Manifacturer } \\
\hline & $\begin{array}{l}\frac{\lambda}{\sqrt{0}} \\
\mathbb{0} \\
0 \\
0 \\
0 \\
0\end{array}$ & $\stackrel{\mathscr{E}}{\stackrel{\mathscr{E}}{\Sigma}}$ & 录 & 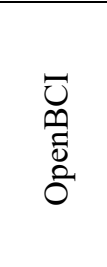 & 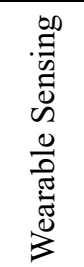 & 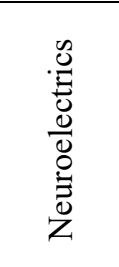 & 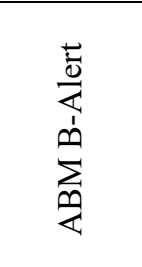 & 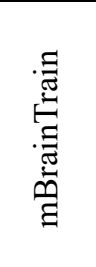 & 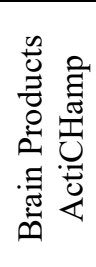 & $\begin{array}{l}\vec{\Xi} \\
D \\
\tilde{D} \\
.0 \\
\dot{0}\end{array}$ & 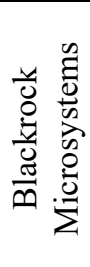 \\
\hline Price range & \multicolumn{4}{|c|}{ Lower } & \multicolumn{4}{|c|}{ Middle } & \multicolumn{3}{|c|}{ High } \\
\hline Price, $\$$ & 200 & 380 & $\begin{array}{l}300 / \\
850\end{array}$ & 800 & $\begin{array}{l}7 \mathrm{~K} / \\
20 \mathrm{~K}\end{array}$ & - & $2,5 \mathrm{~K} / 3 \mathrm{~K}$ & $6,5 \mathrm{~K}$ & $28 \mathrm{~K}$ & - & - \\
\hline $\begin{array}{l}\text { Number of active } \\
\text { sensors }\end{array}$ & 1 & 4 & $5 / 14$ & $4 / 8 / 16$ & $7 / 21$ & $8 / 20 / 32$ & $9 / 20$ & 24 & 32 & $\begin{array}{l}32 / \\
256\end{array}$ & - \\
\hline Non-invasivity & Yes & Yes & Yes & Yes & Yes & Yes & Yes & Yes & Yes & Yes & No \\
\hline $\begin{array}{l}\text { Software for } \\
\text { developers }\end{array}$ & Yes & Yes & Yes & No & Yes & Yes & Yes & Yes & Yes & Yes & No \\
\hline $\begin{array}{l}\text { Wireless } \\
\text { connection }\end{array}$ & Yes & Yes & Yes & Yes & Yes & Yes & Yes & Yes & No & No & No \\
\hline $\begin{array}{l}\text { Outputs data on } \\
\text { smartphone }\end{array}$ & Yes & Yes & Yes & No & No & Yes & No & Yes & No & No & No \\
\hline $\begin{array}{l}\text { Outputs data on } \\
\text { computer }\end{array}$ & Yes & Yes & Yes & Yes & Yes & Yes & Yes & Yes & Yes & Yes & Yes \\
\hline Reads EEG & Yes & Yes & Yes & Yes & Yes & Yes & Yes & Yes & Yes & Yes & Yes \\
\hline Reads EMG & Yes & Yes & Yes & Yes & Yes & No & Yes & No & No & No & No \\
\hline Reads ECG & Yes & Yes & No & Yes & Yes & No & Yes & No & No & No & Yes \\
\hline $\begin{array}{l}\text { Presence of an } \\
\text { accelerometer }\end{array}$ & No & No & Yes & Yes & Yes & Yes & Yes & Yes & No & No & Yes \\
\hline $\begin{array}{l}\text { Presence of } \\
\text { gyroscopes }\end{array}$ & No & No & Так & No & Yes & No & No & No & No & No & No \\
\hline SD card support & No & No & No & No & No & Yes & Yes & Yes & No & No & No \\
\hline $\begin{array}{l}\text { Control of game } \\
\text { character }\end{array}$ & Yes & No & Yes & Yes & Yes & No & No & No & No & No & No \\
\hline $\begin{array}{l}\text { Heart rate } \\
\text { monitoring }\end{array}$ & Yes & Yes & No & Yes & No & No & No & No & No & No & Yes \\
\hline $\begin{array}{l}\text { Monitoring of } \\
\text { tiredness }\end{array}$ & Yes & No & No & No & No & No & No & No & No & No & No \\
\hline $\begin{array}{l}\text { Monitiring of } \\
\text { attentiveness }\end{array}$ & Yes & No & No & No & No & No & No & No & No & No & No \\
\hline
\end{tabular}

All mid-range neural devices $(\$ 1,000-\$ 25,000)$ are research ones. Some companies (ABM, mBrainTrain, Neuroelectrics and Wearable Sensing) offer wireless solutions in this price range that allow data collection with increased mobility (and increased comfort). In addition, ANT Neuro, Neuroelectrics and Wearable Sensing offer the ability to collect EEG data without conductive gel, which reduces data collection time.

In the upper price range (from $\$ 25,000$ and up), there are many devices on the market with a large number of electrode channels, ranging from 32 (Brain Product's ActiCHamp) to 
160 or even 256 channels (BioSemi). This number of channels provides high resolution in the recognition of brain control signals. Blackrock Microsystems developments underpin the world's most innovative human neuroprosthesis projects. These include projects that allow people with paralysis to control robotic manipulators with a high degree of freedom - using only their thoughts. The use of two NeuroPort modules gives the researcher access to hundreds of neurons and allows recording signals from two different areas in the flow of motoric control of the brain. This ensures enhanced neural signal input to the researcher's control algorithms and allows the patient to control complex robotic devices. The NeuroPort system comes with a multifunctional API that provides the researcher's custom software with an easy way to connect to the system and access data over the Internet.

Signal processing by the neurointerface system can be divided into five stages (Fig. 2): signal registration, signal pre-processing, evaluation of signal characteristics, signals classification (recognition) and computer interaction [7].

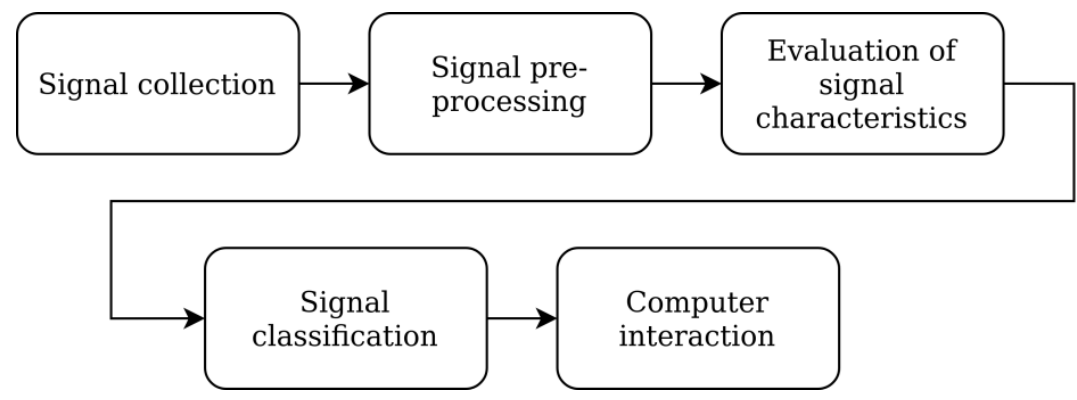

Figure 2. Main stages of signal processing by the neurointerface system

Recording of brain signals can be performed using various non-invasive methods, such as electroencephalography (EEG), functional magnetic resonance imaging (fMRI), near infrared spectroscopy (nIRS) and magnetic encephalography (MEG) (Table 3).

Table 3

Comparison of different methods of signal acquisition in neurointerface systems

\begin{tabular}{|c|c|c|c|c|}
\hline & EEG & fMRT & nIRS & MEG \\
\hline $\begin{array}{l}\text { Way of } \\
\text { receiving } \\
\text { signal }\end{array}$ & $\begin{array}{l}\text { Electric signal is read } \\
\text { from the surface of the } \\
\text { scalp using electrodes }\end{array}$ & $\begin{array}{l}\text { Metabolic signals are } \\
\text { recorded by } \\
\text { determining blood } \\
\text { oxygenation }\end{array}$ & $\begin{array}{l}\text { Metabolic signals are } \\
\text { recorded by } \\
\text { determining blood } \\
\text { oxygenation }\end{array}$ & $\begin{array}{l}\text { Magnetic signals } \\
\text { generated by the } \\
\text { electrical activity of } \\
\text { the brain }\end{array}$ \\
\hline Advantages & $\begin{array}{l}\text { High temporal } \\
\text { resolution, security, } \\
\text { availability }\end{array}$ & $\begin{array}{l}\text { High temporal and } \\
\text { spatial resolution }\end{array}$ & High spatial resolution & $\begin{array}{l}\text { Broad frequency } \\
\text { range, high temporal } \\
\text { and spatial resolution }\end{array}$ \\
\hline Disadvantages & $\begin{array}{l}\text { Low spatial } \\
\text { resolution, artifacts } \\
\text { from eye movement } \\
\text { and blinking, } \\
\text { heartbeat, etc }\end{array}$ & $\begin{array}{l}\text { Expensive and bulky } \\
\text { equipment, high data } \\
\text { collection delay }\end{array}$ & $\begin{array}{l}\text { Low performance and } \\
\text { temporal resolution }\end{array}$ & $\begin{array}{l}\text { Expensive, bulky, } \\
\text { difficult to install }\end{array}$ \\
\hline
\end{tabular}

Electroencephalography (EEG) is the most widely available method of recording brain activity in neurointerface systems today. It allows recording electrical potentials on the surface of the scalp, which are associated with the work of the brain. Electroencephalography has more than a century of history, and although it was originally used more in psychology, medicine and 
neurology, today this method is widely used in games, human-computer interaction, neuromarketing, modeling, and more. In most electroencephalography studies, the EEG signal is analyzed in the classical frequency range borrowed from clinical practices: delta-rhythm (1$4 \mathrm{~Hz})$, theta-rhythm $(4-8 \mathrm{~Hz})$, alpha-rhythm $(8-14 \mathrm{~Hz})$, beta-rhythm $(14-30 \mathrm{~Hz})$, gammarhythm $(30-50 \mathrm{~Hz})$, etc. [8]. Rhythm is considered as the EEG signal manifestation in a certain frequency range. Rhythm depression is a decrease in the EEG signal without changing its frequency response.

Functional magnetic resonance imaging or fMRI is a type of magnetic resonance imaging that is performed to measure hemodynamic reactions caused by the neural activity of the brain or spinal cord. This method is based on the fact that cerebral circulation and neuronal activity are interrelated; that is, when an area of the brain is active, blood flow to that area increases [8]. Nowadays it is one of actively developing type of neuroimaging. Since the early 1990s, fMRI has become dominant in the field of brain imaging due to its low invasiveness. In the article [10] «Sharing deep generative representation for perceived image reconstruction from human brain activity» Changde Du, Changying Du and Huiguang He from the China Academy of Sciences have demonstrated the new ways of fMRI data analysis. Experts from the Beijing Research Center used neural networks, which consistently taught to determine the relationship between what a person sees and brain activity recorded by fMRI. Subsequently, the neural network learned to reproduce the original image with a high degree of accuracy.

Near-infrared spectroscopy is a spectroscopic method that uses the near-infrared region of the electromagnetic spectrum. Near-infrared spectroscopy technology has low resolution, and this can in some cases reduce the performance of the neurointerface, including speed. To solve this problem, near-infrared spectroscopy technology is combined with EEG. This type of neurointerfaces is also called hybrid.

Magnetic encephalography (MEG) is very similar to EEG, but it is devoid of some EEG shortcomings. With MEG technology, magnetic signals generated due to the electrical activity of the brain are recorded. This technology provides a wider frequency range and high spatiotemporal resolution, but it requires expensive and bulky equipment [11].

After receiving the signal by one of the registration methods, it is necessary to preprocess it to clean the signal from noise and artifacts. This stage is also called pre-amplification of the signal [7]. Artifacts can be removed using the following methods [12]: Common Average Referencing (CAR), Independent Component Analysis (ICA), Common Spatial Patterns (CSP), Surface Laplacian (SL), Common Spatio-Spatial Patterns (CSSP), Adaptive Filtering (AF) etc. The above methods are most often used in neurointerface technologies (Table 4 [33]).

CAR is one of the methods, the essence of which is that the potential of the electrical signal at each of the electrodes is measured relative to the average value of the electrical potential of all electrodes [13]. Studies show that CAR outperforms all pre-treatment methods and shows the best results [14].

The ICA method was first applied to the EEG by Scott McEig in 1996. ICA separates artifacts from EEG signals by decomposing them into independent Gaussian components based on the characteristics of the received signal, without relying on reference channels [15]. As a result, the method requires significant calculated resources for signal decomposition, but it demonstrates high performance when the data size for decomposition is large [16].

CSP is a method used in signal processing to divide it into additional subcomponents that have maximum differences while processing by two different sliding windows [17]. CSP uses spatial filtering and uses spatial information to detect patterns in the EEG. This method is sensitive to artifacts and electrodes position, so changing the position of the electrodes during the experiment can reduce the accuracy of the results. [18]. There is an improved version of this method - CSSP. However, like CSP, CSSP is more sensitive to non-stationary EEG. 
Table 4

Comparison of EEG-signal pre-processing methods

\begin{tabular}{|c|c|c|}
\hline Method & Advantages & Disadvantages \\
\hline CAR & $\begin{array}{c}\text { The most effective of all reference methods, } \\
\text { easy to implement }\end{array}$ & $\begin{array}{c}\text { Incomplete coverage of the head with electrodes } \\
\text { causes problems in calculating the average } \\
\text { values }\end{array}$ \\
\hline ICA & $\begin{array}{c}\text { Has high computational efficiency for large } \\
\text { amounts of data }\end{array}$ & $\begin{array}{c}\text { Requires significant computing resources for } \\
\text { decomposition }\end{array}$ \\
\hline $\begin{array}{c}\text { CSP and } \\
\text { CSSP }\end{array}$ & $\begin{array}{c}\text { Does not require pre-selection of subspecific } \\
\text { ranges and knowledge of these ranges }\end{array}$ & $\begin{array}{c}\text { Sensitive to artifacts and changes in electrode } \\
\text { position during the experiment }\end{array}$ \\
\hline SL & $\begin{array}{c}\text { Resistant to artifacts that occur in areas where } \\
\text { electrodes are not installed }\end{array}$ & $\begin{array}{c}\text { Sensitive to spline patterns and artifacts } \\
\text { AF }\end{array}$ \\
$\begin{array}{c}\text { Allows changing the characteristics of the } \\
\text { filter depending on the input signal; filters } \\
\text { artifacts when superimposing signal spectra }\end{array}$ & $\begin{array}{c}\text { The result of calculating the root mean square } \\
\text { filtering error may not always be relevant }\end{array}$ \\
\hline
\end{tabular}

The SL method [19] is a spatial filter in which signals (spatially averaged) of its nearest neighbors ( $\mathrm{N}$, usually 4 or 8 ) are subtracted from the signal of each channel. This is implemented by high-frequency spatial filter that dampens large-scale scalp signals and amplifies localized signals.

$\mathrm{AF}$ is a filter that independently adjusts its transmitting function according to an optimization algorithm using an error signal. Since the parameters of the adaptive filter change during its operation, such a filter can be classified as nonlinear device. However, for each fixed value of the parameters, the adaptive filter is a linear device, because between its input and output signals usually there is a linear relationship due to the current set of weights, similar to linear filters with fixed weights [20]. The disadvantage of a conventional filter is that when the signal and noise in the frequency domain significantly overlap, the filter removes the useful signal. This problem can be easily solved by means of adaptive filter. That is, artifacts from the EEG signal can be effectively removed using least squares algorithms. Using this algorithm, the optimization of the root mean square error is achieved [21].

After the stage of amplifying the EEG signal, it is necessary to distinguish its main characteristics. To do this, models of adaptive parameters of autoregression (AAR), bilinear AAR, multidimensional AAR, fast Fourier transform (FFT), Wavelet transform (WT), wave packet decomposition (WPD), etc. are used [12] (Table 5 [33]).

Autoregressive (AR) methods are used to extract the characteristics of signals in time domain. The essence of the method is to reduce the recording time of the signal, which increases the resolution in the frequency domain and almost eliminates the problem of spectral losses. Most frequently, they are used for processing non-stationary signals (for example for EEG). The following auto-regression methods are used for EEG: bilinear AAR, multidimensional AAR. The latter method shows the best performance, and achieves a classification accuracy of $83 \%$ [22].

Fast Fourier Transform (FFT) is a fast algorithm for calculating a discrete Fourier transform. If the direct calculation of the discrete Fourier transform from $\mathrm{N}$ data points requires $O\left(N^{2}\right)$ arithmetic operations, then FFT allows calculating the same result using $O(N \log N)$ operations.

Wavelet transforms were introduced by Grossman and Morlett in 1984 [23]. Working on the theory of digital signal processing, S. Mallat introduced a new approach to the theory of 
wavelets, combining the ideas of filtering with mirror symmetry, the pyramidal algorithm and the orthogonal basis of wavelets [24].

The wave packet is a superposition of monochromatic plane waves formed in such a way as to limit the perturbation region [25]. The wave packet decomposition method can stretch functions in both the time and frequency domains with an average wavelet conversion factor. In Fisher's criterion [26], the coefficients with higher separation are considered effective and are formed as a finite vector. It divides the output signal into two subspaces depending on the frequency, demonstrates good efficiency in the process of selecting the characteristics of nonstationary signals, such as EEG [26].

Table 5

Comparison of methods for selecting EEG-signal characteristics

\begin{tabular}{|c|c|c|}
\hline Method & Advantages & Disadvantages \\
\hline $\begin{array}{c}\text { AR (AAR, } \\
\text { BAAR } \\
\text { etc.) }\end{array}$ & $\begin{array}{c}\text { Reduces spectral loss problems and provides } \\
\text { better frequency resolution; shorter data } \\
\text { records are required }\end{array}$ & $\begin{array}{c}\text { Not applicable to non-stationary signal; there } \\
\text { are difficulties in establishing the properties of } \\
\text { the model for EEG signals }\end{array}$ \\
\hline FFT & One of the best methods for frequency analysis & $\begin{array}{c}\text { Applied only to stationary signals and linear } \\
\text { random processes; high noise sensitivity }\end{array}$ \\
\hline WT & $\begin{array}{c}\text { Able to analyze the signal with gaps due to the } \\
\text { variable window size; can analyze signals in } \\
\text { both time and frequency domains }\end{array}$ & $\begin{array}{c}\text { Lack of methodology for application to } \\
\text { comprehensive noise; productivity is limited by } \\
\text { Heisenberg indeterminance }\end{array}$ \\
\hline WPD & Is able to analyze non-stationary signals & Long calculation time \\
\hline
\end{tabular}

Having extracted the necessary characteristics of the signal using the above methods, it is necessary to bring the signal into different classes, using classifiers: linear classifiers (discriminant analysis, reference vector method), nonlinear Bayesian classifiers, nearest neighbor classifiers, artificial neural networks, etc. (Table 6 [33, 36, 37]).

Linear classifiers use linear functions to classify signals by class. The most commonly used linear classifiers are linear discriminant analysis (LDA) and the reference vector method (SVM) [27].

Linear discriminant analysis is a type of multidimensional analysis designed to solve image recognition problems. It is used to decide which variables divide certain data sets. Discriminant analysis is close to variance and regression analysis, which also tend to express one of the dependent variables in the form of a linear combination of other indicators or measurements [28]. The classifier is easy to use and has very low computational requirements. If the discriminant function is not in the average value, but in the data variance, then linear discriminant analysis cannot be used [29].

The reference vector method is a method of data analysis for classification and regression analysis using controlled learning models with related learning algorithms called reference vector machines. [30]. This linear classifier is used by most brain-computer interface programs. It was developed by Volodymyr Vapnyk and is controlled by the statistical theory of learning, adhering to the principle of minimizing structural risks [30]. The task of this method is to provide good generalization, maximizing the performance of the machine, minimizing the complexity of the studied model [31]. 
Table 6

Comparison of EEG-signal classification methods

\begin{tabular}{|c|c|c|}
\hline Method & Advantages & Disadvantages \\
\hline LDA & $\begin{array}{l}\text { Does not require high computational resources, } \\
\text { user-friendly }\end{array}$ & $\begin{array}{l}\text { Unapplicable if the discriminant function is not } \\
\text { average; for non-Gaussian distributions, the } \\
\text { classifier may not retain complex structures }\end{array}$ \\
\hline SVM & $\begin{array}{c}\text { Has higher performance than other linear } \\
\text { classifiers }\end{array}$ & Requires high computational resources \\
\hline $\mathrm{NBC}$ & $\begin{array}{l}\text { Only a small amount of learning data is required } \\
\text { to evaluate the parameters }\end{array}$ & $\begin{array}{l}\text { The classifier is not able to make a sufficient } \\
\text { estimate for the probabilities of classes }\end{array}$ \\
\hline $\begin{array}{l}\mathrm{NNCs} \\
(\mathrm{k}-\mathrm{NN})\end{array}$ & $\begin{array}{l}\text { Does not require high computational resources, } \\
\text { user-friendly }\end{array}$ & $\begin{array}{l}\text { Low performance when learning set is large; } \\
\text { sensitive to irrelevant and redundant functions }\end{array}$ \\
\hline ANN & $\begin{array}{l}\text { Low learning requirements; easy to implement } \\
\text { and learn }\end{array}$ & $\begin{array}{c}\text { Efficiency depends on the number of neurons in } \\
\text { the hidden layer }\end{array}$ \\
\hline
\end{tabular}

Nonlinear Bayesian classifiers (NBCs) are generative in nature and allow more efficient deviations of indeterminate samples than discriminant classifiers. The hidden Markov model is most often used in neurointerfaces. This model is a dynamic nonlinear Bayesian classifier. The hidden Markov model is a statistical Markov model in which the system being modeled is considered as a Markov process with unobservable states [32].

Neighbor Classifiers (NNCs) assign a vector of class attributes based on the nearest neighbors, if the feature vector comes from a learning set, it is called the classifier of $\mathrm{k}$-nearest neighbors [33]. This is a simple non-parametric classification method, where distances (usually Euclidean) are used to classify objects within the property space, calculated for all other objects, objects with the smallest distance are selected, and they are allocated to a separate class [34]. The classifier of k-nearest neighbors is very simple to understand, implement and debug [32].

Artificial neural networks (ANNs) are nonlinear classifiers that consist of a large number of interconnected simple elements, so-called neurons. Neurons receive an input, change their internal state (excitation) according to this input, and produce an output that depends on input and excitation. The network is formed by connecting the outputs of certain neurons with the inputs of other neurons with the formation of an oriented weighted graph. Weights, as well as functions that calculate excitation, can vary in a process called learning, which is guided by the rule of learning [35]. The most commonly used is multilayer perceptron neural network (MLPNN), in which the network consists of three layers, namely the input layer, the hidden layer and the output layer. In practice, the required number of neurons in the hidden layer is determined by trial and error.

Approach to a reasonable choice of methods, hardware and software for the development of neurointerface systems in the applied areas of their possible application.

Based on the above material concerning the comparative analysis of methods and tools of neurointerface systems, there can be offered the following generalized approach to a reasonable choice of methods and software and hardware for the development of neurointerface systems in the field of their possible application.

First of all, it should be taken into account that signal processing by any neurointerface system is basically divided into five stages: signal registration, signal pre-processing, evaluation of signal characteristics, signal classification, and computer interaction. Selection of signal processing methods in the first stage will determine the choice of signal processing methods in the future. When choosing methods based on EEG registration as one of the most 
available options, attention should be payed to the optimal number of channels and type of electrodes for research, as this will depend on the spatial resolution and sensitivity of the resulting neurointerface system. Also, the choice of the number and type of electrodes will determine the time of the experiment, because setting electrodes needs application of a special conductive gel, so extra time will be spent. In contrast, dry electrodes are easy to install, but have less sensitivity.

The next important step is to choose the method of signal pre-processing. For example, the CAR method is the most efficient of all reference methods and easy to implement, but if the previous stage EEG with insufficient channels was chosen, the CAR method is not suitable, because incomplete coverage of the head with electrodes causes problems in calculating the average values of space-time signal.

Using the above principle of method selection and combining them at each stage, better results can be always achieved when developing neurointerface systems. In the future, this will allow the development of a neural interface that will simplify the interaction with computer operating systems, which in turn automates the interaction with both household appliances and complex systems in medicine and other areas of human activity.

Conclusions. In the article, the existing neurointerfaces are compared, namely, different price segments of the market are considered and the relevant products from different manufacturers of neurointerface systems are compared, in particular, companies such as ANT Neuro, Neuroelectrics and Wearable Sensing, ABM, Blackrock Microsystems and mBrainTrain.

Based on five main stages developed in the process of signal processing in the neurointerface information systems of human-machine interaction, namely, signal registration, pre-processing of signals, evaluation of signal characteristics, classification (recognition) of signals and computer interaction, a comparative analysis at each of these stages of known methods and means of neurointerface technologies is made. In particular, the analysis of such typical methods of signal registration as electroencephalography, magnetic encephalography, functional magnetic resonance imaging and near infrared spectroscopy, which allowed to establish a number of significant advantages of electroencephalography as a promising method of non-invasive neurointerface technologies, is carried out.

In the context of signal pre-processing, advantages and disadvantages of such methods as Common Average Referencing, Independent Component Analysis, Common Spatial Patterns, Surface Laplacian, Common Spatio-Spatial Patterns and Adaptive Filtering are considered. At the stage of evaluating the informative characteristics of the signal, the analysis of models and methods based on the models of adaptive parameters of autoregression, bilinear autoregression, multidimensional autoregression, fast Fourier transform, wavelet transform, wave packet decomposition is performed. Besides, a comparative analysis of the most common methods of identification (recognition) of control effects of the human neurointerface operator, namely, the method of discriminant analysis, the method of reference vectors, nonlinear Bayesian classifiers, classifiers of nearest neighbors, artificial neural networks is carried out.

Based on the comparative analysis of known methods and tools of neurointerface systems, a generalized approach to a reasonable choice of methods and software and hardware in the development of neurointerface systems in various application areas of their possible application is suggested.

\section{References}

1. Tufte, E. R. "Envisioning Information.” Cheshire, CT: Graphics Press, 1990.

2. Suchman, L. A. "Plans and situated actions: the problem of human-machine communication." Cambridge University Press, Cambridge, UK 1987. 
3. Lupenko S. A., Butsiy R. A. "Modern neurointerface technologies: actuality, prospects and complexities", International Scientific and Technical Conference "Ivan Puluj: life in the name of science and Ukraine", 2020. P. 81-82.

4. Shih J., Krusienski D., Wolpaw J., "Brain-Computer Interfaces in Medicine". Mayo Clin Pro. Vol. 87. No. 3, 2012. P. 268-279. DOI: https://doi.org/10.1016/j.mayocp.2011.12.008

5. Wolpaw J., McFarland D., "Control of a two-dimensional movement signal by a noninvasive brain-computer interface in humans". Proc Natl Acad Sci. Vol. 101. No. 51. 2004. DOI: https://doi.org/10.1073/pnas.0403504101

6. ButsIy R., Lupenko C. AnalIz osnovnih harakteristik komertsIynih neyroInterfeysIv. IX MIzhnarodna naukovo-tehnIchna konferentsIya molodih uchenih ta studentIv "AktualnI zadachI suchasnih tehnologIy", 25-26 listopada 2020 r.: tezi dop. TernopIl, 2020. Tom 2. P. 9-10.

7. T. Kameswara Rao, M. Rajya Lakshmi, Dr. T. V. Prasad, "An Exploration of Brain Computer Interface and Its Recent Trends", Int. J. of Advanced Research in Artificial Intelligence. Vol. 1. No. 8. 2012. DOI: https://doi.org/10.14569/IJARAI.2012.010804

8. William O., Ellen R., "Grass Lecture: Extraordinary EEG”, Neurodiagnostic Journal. Vol. 54.2014. P. 3-21.

9. Logothetis N., Pauls J., Auguth M., Trinath T., Oeltermann A., "A neurophysiological investigation of the basis of the BOLD signal in fMRI". Nature. Vol. 412. 2001. P. 150-157. DOI: https://doi.org/10.1038/35084005

10. Changde Du., Changying Du., Huiguang He. "Sharing deep generative representation for perceived image reconstruction from human brain activity". International Joint Conference on Neural Networks. 2017.

11. Aruna T., Vijay N., "Brain-computer interface: a thought translation device turning fantasy into reality", Int. J. Biomedical Engg. and Tech. Vol. 11. No. 2. 2013. DOI: https://doi.org/10.1504/IJBET.2013.055044

12. ButsIy R., Lupenko C. AnalIz metodIv dlya zadach opratsyuvannya signalIv neyroInterfeysnih sistem. VIII Naukovo-tehnIchna konferentsIya "InformatsIynI modelI, sistemi ta tehnologIYi", 9-10 grudnya 2020 r.: tezi dop. TernopIl, 2020. P. 3.

13. D. J. McFarland, L. M. McCane, S. V. David, and J. R. Wolpaw, "Spatial filter selection for EEGbased communication”, Electroencephalogr. Clin. Neurophysiol. Vol. 103. No. 3.1997. P. 386-394. DOI: https://doi.org/10.1016/S0013-4694(97)00022-2

14. Mohammed J., "Common Average Reference (CAR) Improves P300 Speller", Int. J. of Engg. and Tech. Vol. 2. No. 3. 2012.

15. Arnaud D., Scott M., "EEGLAB: an open source toolbox for analysis of single-trial EEG dynamics including independent component analysis". J. of Neuroscience Methods. Vol. 134. 2004. DOI: https://doi.org/10.1016/j.jneumeth.2003.10.009

16. Jung T., Makeig S. and Humphries S., "Extended ICA Removes Artefacts from Electroencephalographic Recording”, Advances in Neural Inf. Processing Systems. Cambridge. Vol. 10. 1998.

17. Koles J., Lazaret S., Zhou Z., "Spatial patterns underlying population differences in the background EEG". Brain topography. Vol. 2. 1990. P. 275-284. DOI: https://doi.org/10.1007/BF01129656

18. Fabien L. and Cuntai G., "Regularizing Common Spatial Patterns to Improve BCI Designs: Unified Theory and New Algorithms". IEEE Trans. On Biomedical Engg. Vol. 58. No. 2. 2011. DOI: https://doi.org/10.1109/TBME.2010.2082539

19. Hjorth B., "An on-line transformation of EEG scalp potentials into orthogonal source derivations", Electroencephalography and Clinical Neurophysiology. Vol. 2. 1975. P. 526-530. DOI: https://doi.org/10.1016/0013-4694(75)90056-5

20. Thakor N. and Zhu Y., "Applications of adaptive filtering to ECG analysis: noise cancellation and arrhythmia detection", IEEE Transactions on Biomedical Engineering. Vol. 38. 1991. P. 785-794. DOI: https://doi.org/10.1109/10.83591

21. Chandrakar C. and Kowar M., "De-noising ECG Signals Using Adaptive Filter Algorithm”, Int. J. of Soft Computing and Engg. Vol. 2. No 1. 2012.

22. AlMejrad S. "Human Emotions Detection using Brain Wave Signals", European Journal of Scientific Research. Vol. 4. 2010.

23. Grossmann A. and Morlet J. "Decomposition of Hardsi functions into square integrable wavelets of constant shape". SIAM J. Math. Vol. 15. 1984. P. 723-736. DOI: https://doi.org/10.1137/0515056

24. Mallat S. "Multiresolution representations and wavelets", Ph.D. Thesis, University of Pennsylvania, Philadelphia. 1988.

25. Einstein A. "On a Heuristic Viewpoint Concerning the Production and Transformation of Light". Annalen der Physik. Vol. 17.1905. P. 132-148. DOI: https://doi.org/10.1002/andp.19053220607

26. Wu T., Yan G., Yang B., Sun H. "EEG feature extraction based on wavelet packet decomposition for brain computer interface". Elsevier. Vol. 41. 2008. P. 618-625. DOI: https://doi.org/10.1016/j.measurement.2007.07.007 
Comparative analysis of neurointerface technologies for the problem of their reasonable choice in human-machine information systems

27. Lotte F., Bougrain L., Cichocki A., Congedo M. "A A review of classification algorithms for EEG-based brain-computer interfaces: a 10 year update. Journal of Neural Engineering. Vol. 4. 2018. DOI: https://doi.org/10.1088/1741-2552/aab2f2

28. McLachlan G., "Discriminant Analysis and Statistical Pattern Recognition". New Jersey: Wiley Interscience, 2004.

29. Senthilmurugan M., Latha N., Malmurugan N., "Classification in EEG-Based Brain Computer Interfaces Using Inverse Model". Int. J.of Computer Theory and Engg. Vol. 2. 2011.

30. Cortes C., Vapnik V. "Support-vector networks", Machine Learning. Vol. 20. 1995. P. $273-297$. DOI: https://doi.org/10.1007/BF00994018

31. Garrett D., Peterson D., Anderson C., Thaut M. "Comparison of Linear, Nonlinear, and Feature Selection Methods for EEG Signal Classification”. IEEE Trans. on Neural Systems And Rehabilitation Engg. Vol. 11. No. 2. June 2003. DOI: https://doi.org/10.1109/TNSRE.2003.814441

32. Lotte F. "Study of Electroencephalographic Signal Processing and Classification Techniques towards the use of Brain-Co-mputer Interfaces in Virtual Reality Applications". Rennes. 2009.

33. Rajya Lakshmi M., Dr Prasad T. V., Dr Chandra V. "Prakash Survey on EEG Signal Processing Methods", Int. J. of Advanced Research in Computer Science and Software Engineering. Vol. 4. 2014. P. 84-91.

34. Altman N. "An introduction to kernel and nearest-neighbor nonparametric regression". The American Statistician. Vol. 46. 1992. P. 175-185. DOI: https://doi.org/10.1080/00031305.1992.10475879

35. Andreas Z. "Simulation of Neural Networks". Tuebingen: Addison-Wesley, 1994.

36. Lupenko S., Lytvynenko I., Stadnyk N. (2020) Method for reducing the computational complexity of processing discrete cyclic random processes in digital data analysis systems. Scientific Journal of TNTU (Tern.). Vol. 97. No. 1. P. 110-121. DOI: https://doi.org/10.33108/visnyk_tntu2020.01.110

37. Lupenko S. A., Osukhivska H. M., Lutsyk N. S., Stadnyk N. B., Zozulia A. M., Shablii N. R. (2016) The comparative analysis of mathematical models of cyclic signals structure and processes. Scientific Journal of TNTU (Tern.). Vol. 82. No. 2. P. 115-127.

\section{Список використаної літератури}

1. Tufte E. R. «Envisioning Information» Cheshire. CT: Graphics Press, 1990.

2. Suchman L. A. «Plans and situated actions: the problem of human-machine communication.» Cambridge University Press. Cambridge. UK 1987.

3. Lupenko C., ButsIy R. SuchasnI neyroInterfeysnI tehnologiyi: aktualnIst, perspektivi ta skladnosti. Mizhnarodna naukova konferentsIya «Ivan Pulyuy: zhittya v Im'ya nauki ta UkraYini», 28-30 veresnya 2020 r.: tezi dop. TernopIl, 2020. P. 81-82.

4. Shih J., Krusienski D., Wolpaw J. «Brain-Computer Interfaces in Medicine». Mayo Clin Pro. 2012. Tом 87. № 3. C. 268-279. DOI: https://doi.org/10.1016/j.mayocp.2011.12.008

5. Wolpaw J., McFarland D. Control of a two-dimensional movement signal by a noninvasive brain-computer interface in humans. Proc Natl Acad Sci. 2004. Том 101. № 51. DOI: https://doi.org/10.1073/pnas.0403504101

6. Буцій P., Лупенко С. Аналіз основних характеристик комерційних нейроінтерфейсів: IX Міжнародна науково-технічна конференція молодих учених та студентів «Актуальні задачі сучасних технологій», 25-26 листопада 2020 р.: тези доп. Тернопіль, 2020. Том 2. С. 9-10.

7. T. Kameswara Rao, M. Rajya Lakshmi, Dr. T. V. Prasad. An Exploration of Brain Computer Interface and Its Recent Trends. Int. J. of Advanced Research in Artificial Intelligence. 2012. Том 1. № 8. DOI: https://doi.org/10.14569/IJARAI.2012.010804

8. William O. Ellen R. Grass Lecture: Extraordinary EEG. Neurodiagnostic Journal. 2014. Tом 54. C. 3-21.

9. Logothetis N., Pauls J., Auguth M. A neurophysiological investigation of the basis of the BOLD signal in Fmri. Nature. 2001. Tом 412. C. 150-157. DOI: https://doi.org/10.1038/35084005

10. Changde Du., Changying Du., Huiguang He. Sharing deep generative representation for perceived image reconstruction from human brain activity. International Joint Conf. on Neural Networks, 2017.

11. Aruna T., Vijay N. Brain-computer interface: a thought translation device turning fantasy into reality. Int. J. Biomedical Engg. and Tech. 2013. Том 11. № 2. DOI: https://doi.org/10.1504/IJBET.2013.055044

12. Буцій Р., Лупенко С. Аналіз методів для задач опрацювання сигналів нейроінтерфейсних систем: VIII Науково-технічна конференція «Інформаційні моделі, системи та технології», 9-10 грудня 2020 р.: тези доп. Тернопіль, 2020. С. 3.

13. McFarland D., McCane L., David S., Wolpaw J. Spatial filter selection for EEG based communication. Electroencephalogr. Clin. Neurophysiol. 1997. Том 103. № 3. C. 386-394. DOI: https://doi.org/10.1016/S0013-4694(97)00022-2

14. Mohammed J. Common Average Reference (CAR) Improves P300 Speller. Int. J. of Engg. and Tech. 2012. Том 2. № 3. 
15. Arnaud D., Scott M. EEGLAB: an open source toolbox for analysis of single-trial EEG dynamics including independent component analysis. J. of Neuroscience Methods. 2004. Tom 134. DOI: https://doi.org/10.1016/j.jneumeth.2003.10.009

16. Jung T., Makeig S., Humphries C. Extended ICA Removes Artefacts from Electroencephalographic Recording. Advances in Neural Inf. Processing Systems. 1998. Tом 10.

17. Koles J., Lazaret S., Zhou Z. Spatial patterns underlying population differences in the background EEG. Brain topography. 1990. Tом 2. C. 275-284. DOI: https://doi.org/10.1007/BF01129656

18. Fabien L., Cuntai G. Regularizing Common Spatial Patterns to Improve BCI Designs: Unified Theory and New Algorithms. IEEE Trans. On Biomedical Engg. 2011. Toм 58. № 2. DOI: https://doi.org/10.1109/TBME.2010.2082539

19. Hjorth B. An on-line transformation of EEG scalp potentials into orthogonal source derivations. Electroencephalography and Clinical Neurophysiology. 1975. Tом 39. C. 526-530. DOI: https://doi.org/10.1016/0013-4694(75)90056-5

20. Thakor N., Zhu Y. Applications of adaptive filtering to ECG analysis: noise cancellation and arrhythmia detection. IEEE Transactions on Biomedical Engineering. 1991. Tом 38. C. 785-794. DOI: https://doi.org/10.1109/10.83591

21. Chandrakar C., Kowar M. De-noising ECG Signals Using Adaptive Filter Algorithm. Int. J. of Soft Computing and Engg. 2012. Tом 2. № 1.

22. AlMejrad S. Human Emotions Detection using Brain Wave Signals. A Challenging, European Journal of Scientific Research. 2010. Tом 4.

23. Grossmann A., Morlet J. Grossmann A. Decomposition of Hardsi functions into square integrable wavelets of constant shape. SIAM J. Math. 1984. Toм 15. C. 723-736. DOI: https://doi.org/10.1137/0515056

24. Mallat S. Multiresolution representations and wavelets, Ph.D. Thesis, University of Pennsylvania, Philadelphia. 1988.

25. Einstein A. On a Heuristic Viewpoint Concerning the Production and Transformation of Light. Annalen der Physik. 1905. Tом 17. C. 132-148. DOI: https://doi.org/10.1002/andp.19053220607

26. Wu T., Yan G., Yang B., Sun H. EEG feature extraction based on wavelet packet decomposition for brain computer interface. Elsevier. 2008. Toм 41. C. 618-625. DOI: https://doi.org/10.1016/j.measurement.2007.07.007

27. Lotte F., Bougrain L., Cichocki A. A review of classification algorithms for EEG-based brain-computer interfaces: a 10 year update.Journal of Neural Engineering. 2018. Tом 4. DOI: https://doi.org/10.1088/1741-2552/aab2f2

28. McLachlan G. Discriminant Analysis and Statistical Pattern Recognition. New Jersey: Wiley Interscience, 2004.

29. Senthilmurugan M., Latha M., Malmurugan N. Classification in EEG-Based Brain Computer Interfaces Using Inverse Model. Int. J. of Computer Theory and Engg. 2011. Tом 2.

30. Cortes C., Vapnik V. Support-vector networks. Machine Learning. 1995. Tом 20. C. $273-297$. DOI: https://doi.org/10.1007/BF00994018

31. Garrett D., Peterson D., Anderson C., Thaut M. Comparison of Linear, Nonlinear, and Feature Selection Methods for EEG Signal Classification. IEEE Trans. on Neural Systems And Rehabilitation Engg. 2003. Toм 11. № 2. DOI: https://doi.org/10.1109/TNSRE.2003.814441

32. Lotte F. Study of Electroencephalographic Signal Processing and Classification Techniques towards the use of Brain-Co-mputer Interfaces in Virtual Reality Applications: Ph D. Rennes, 2009.

33. M. Rajya Lakshmi, Dr. T. V. Prasad, Dr. V. Chandra Prakash. Survey on EEG Signal Processing Methods. Int. J. of Advanced Research in Computer Science and Software Engineering. 2014. Tом 4. C. 84-91.

34. Altman N. An introduction to kernel and nearest-neighbor nonparametric regression. The American Statistician. 1992. Tом 46. C. 175-185. DOI: https://doi.org/10.1080/00031305.1992.10475879

35. Andreas Z. Simulation of Neural Networks. Tuebingen: Addison-Wesley, 1994.

36. Lupenko S., Lytvynenko Ia., Stadnyk N. Method for reducing the computational complexity of processing discrete cyclic random processes in digital data analysis systems. Scientific Journal of TNTU (Tern.). Vol. 97. No. 1. P. 110-121. DOI: https://doi.org/10.33108/visnyk_tntu2020.01.110

37. Lupenko S., Osukhivska H., Lutsyk N., Stadnyk N., Zozulia A., Shablii N. The comparative analysis of mathematical models of cyclic signals structure and processes. Scientific Journal of TNTU (Tern.). Vol. 82. No. 2. P. 115-127. 
УДК 004.021:004.77

\title{
КОМПАРАТИВНИЙ АНАЛІЗ НЕЙРОІНТЕРФЕЙСНИХ ТЕХНОЛОГІЙ ДЛЯ ЗАДАЧІ ОБГРУНТОВАНОГО ЇХ ВИБОРУ В ІНФОРМАЦЙНИХ СИСТЕМАХ ЛЮДИНО-МАШИННИХ ВЗАЕМОДІЙ
}

\author{
Роман Буцій ${ }^{1}$ Сергій Лупенко \\ ${ }^{1}$ Інститут телекомунікацій та глобального інформаційного простору, \\ Київ, Украӥна \\ ${ }^{2}$ Тернопільський національний технічний університет імені Івана Пулюя, \\ Тернопіль, Украӥна
}

\begin{abstract}
Резюме. Ринок сучасних нейроінтерфейсів, не зважаючи на свій активний розвиток, нажаль, може запропонувати користувачам лише ряд діючих прототипів, які мають відносно низьку точність та достовірність ідентифікаиії керуючих впливів людини-оператора. Крім того, будь-який нейроінтерфейс, що представлений на ринку, потрібно індивідуально підлаштовувати під кожнулюдинуоператора, щчо ускладнює об’єктивізацію його показників точності, достовірності та надійності функиіонування. Першим етапом вирішення вищезгаданих проблем є проведення компаративного аналізу різних цінових сегментів ринку існуючих нейроінтерфейсних технологій, щзо $і$ зроблено у даній праці. В ході дослідження ринку виявлено, щзо не зважаючи на недоліки електроенцефалографії вона $\epsilon$ одним 3 найдоступніших неінвазивних методів реєстрації біологічних сигналів у нейроінтерфейсних системах. Для полегшення майбутніх досліджень, було розглянуто та проаналізовано основні переваги й недоліки відомих моделей $і$ методів аналізу сигналів в нейроінтерфейсах. Зокрема, в контексті попереднього опрацювання сигналів розглянуто недоліки та переваги таких методів, як Cоттоп Average Referencing, Independent Component Analysis, Common Spatial Patterns, Surface Laplacian, Common Spatio-Spatial Patterns ma Adaptive Filtering. На етапі оцінювання інформативних характеристик сигналу проведено аналіз моделей та методів, щзо трунтуються на моделі адаптивних параметрів авторегресії, білінійної авторегресії, багатовимірної авторегресії, швидкого перетворення Фур'є, вейвлет-перетворення, розкладання хвильових пакетів. Також здійснено порівняльний аналіз найпоширеніших методів ідентифікації керуючих впливів людини-оператора нейроінтерфейса, а саме, метод дискримінантного аналізу, метод опорних векторів, нелінійні баєсівські класифікатори, класифікатори найближчих сусідів, штучні нейронні мережі. На основі наведеного матеріалу запропоновано узагальнений підхід до обтрунтованого вибору методів, моделей та програмно-апаратних засобів для розроблення нейроінтерфейсних систем у прикладних областях їх можливого застосування. Проведене дослідження нейроінтерфейсних технологій надає дослідникам додаткові підстави щзодо обтрунтованого вибору математичного, програмного та апаратного забезпечення нейроінтерфейсних систем, а також сприяє розроблення їх нових версій із підвищеними показниками точності, достовірності та надійності.
\end{abstract}

Ключові слова: нейроінтерфейс, компаративний аналіз, опрацюювання сигналів, електроенцефалограма. 